\title{
Comparison between the Hypolipidemic Activity of Parsley and Carob in Hypercholesterolemic Male Rats
}

\author{
Haddad A. El Rabey, ${ }^{1,2}$ Madeha N. Al-Seeni, ${ }^{1}$ and Habibah B. Al-Ghamdi ${ }^{1}$ \\ ${ }^{1}$ Biochemistry Department, Faculty of Science, King Abdulaziz University, Jeddah, Saudi Arabia \\ ${ }^{2}$ Bioinformatics Department, Genetic Engineering and Biotechnology Research Institute, \\ University of Sadat City, P.O. Box 79, Sadat City, Egypt \\ Correspondence should be addressed to Haddad A. El Rabey; elrabey@hotmail.com
}

Received 10 April 2017; Accepted 20 August 2017; Published 28 September 2017

Academic Editor: Gail B. Mahady

\begin{abstract}
Copyright (C) 2017 Haddad A. El Rabey et al. This is an open access article distributed under the Creative Commons Attribution License, which permits unrestricted use, distribution, and reproduction in any medium, provided the original work is properly cited.
\end{abstract}

\begin{abstract}
Hypercholesterolemia is commonly associated with obesity that leads to heart diseases and diabetes. The hepatocardioprotective activity of parsley and carob methanol extract was tested in hypercholesterolemic male rats. Twenty-four male albino rats were divided into four groups $(n=6)$. Group 1 was the negative control group fed with fat rich diet, group 2 (G2) was hypercholesterolemic rats fed with fat rich diet with $2 \%$ cholesterol, and group 3 and group 4 (G3 and G4) were hypercholesterolemic rats supplemented with $2 \%$ cholesterol and cotreated with $20 \% \mathrm{w} / \mathrm{w}$ parsley seed methanol extract and $20 \%$ w/w carob legume methanol extract, respectively. The experiment was conducted for eight weeks. The positive hypercholesterolemic rats showed significant increase in serum levels of total cholesterol, triglycerides, low density lipoprotein (LDL), very low density lipoprotein (VLDL), lactate dehydrogenase (LDH), creatine kinase-mb, liver function enzymes, and decrease in the high density lipoproteins (HDL). Moreover, heart and liver tissues were ameliorated and nearly restored their normal appearance. It could be concluded that both parsley and carob extracts supplementations have a protective effect against hyperlipidemia and improved the histological alteration in heart and liver tissues. The methanol extract of parsley appeared to be more efficient than that of carob in lowering hypercholesterolemia.
\end{abstract}

\section{Introduction}

Hypercholesterolemia represents a major risk factor for cardiovascular disease (CVD) which continues to remain a significant problem in developed countries and is a growing health concern worldwide $[1,2]$. Taking a high-fat diet and other lifestyle factors like being overweight, smoking, heavy alcohol use, and lack of exercise have been associated with some cancers, for example, postmenopausal breast cancer, prostate cancer, and bowel cancer [3].

Patients with elevated lipids should attempt to correct this abnormality via lifestyle modification, for example, adjustment in diet by minimizing consumption of saturated fat and cholesterol and increase in physical activity [4]. Consumption of soluble fiber such as oat bran and barley bran can lower LDL cholesterol levels [5-7] associated with significant reduction in risk for cardiovascular disease.
Consumption of foods that contain antioxidant compounds protects the low (LDL) and very low density lipoproteins from oxidation, reduces lipid levels in plasma, and thus may reduce risk of cardiovascular disease [8].

Parsley (Petroselinum hortense Mill.) seed is rich in vitamins including $\mathrm{A}$ and $\mathrm{C}$, as well as thiamine, riboflavin, niacin, and minerals including calcium, zinc, potassium, and iron [9]. It also possesses a number of medicinal benefits including antimicrobial, antianemic, menorrhagic, anticoagulant, antihyperlipidemic, antihepatotoxic, antihypertensive, diuretic effects, hypoglycaemic, hypouricemic, antioxidative, and estrogenic activities [10] due to its content of flavonoids, coumarins, ascorbic acid, carotenoids, various terpenoic compounds, phenyl propanoids, phathalides, and tocopherol. Parsley seeds are also rich in monoterpenes (in particular $\alpha$ - and $\beta$-pinene) and oxygenated phenylpropenes, which constitute the greater part of the oil [11-13]. 
Carob legumes have a marked nutritional value due to its high dietary fiber and phenol compounds which exert a preventative role against heart disease and lowering serum cholesterol $[14,15]$. It also contains minerals, amino acids, sugars, and dietary fibers including lignin and polyphenols; flavonol glycoside, $4^{\prime}$-p-hydroxybenzoylisorhamnetin-3-O- $\alpha$-L-rhamnopyranoside named ceratoside, together with the known kaempferol-3-O- $\alpha$-L-rhamnopyranoside (afzelin), quercetin3-O- $\alpha$-L-arabinofuranoside (auriculain), quercetin-3-O- $\alpha \mathrm{L}-$ rhamnopyranoside, $\beta$-sitosterol, and $\beta$-sitosterol-3-O- $\beta$-Dglucoside were isolated from carob seeds [14, 16, 17]. Moreover, carob bean gum increases the dietary fiber in food products without increasing the calories and increases the swelling of the food once in the stomach, which encourages a feeling of fullness, so it is considered a natural appetite suppressant and effective in prevention and treatment of hypercholesterolemia $[18,19]$.

The current study aimed to evaluate the hypolipidemic and antioxidant activity of parsley and carob methanol extract and their potential in protecting heart and liver in hypercholesterolemic male rats.

\section{Materials and Methods}

2.1. Plant Materials. Parsley seeds and carob legumes were purchased from a local herbal medicine shop in Jeddah, Saudi Arabia, identified by Professor Haddad El Rabey (Botanist), and a specimen was deposited in Biochemistry Department, Faculty of Science, KAU, KSA.

2.2. The Lipid Rich Diet. The lipid rich diet consisted of the following: $16 \%$ casein, $10 \%$ corn oil, $4 \%$ N.N cellulose, $4 \%$ salt mixture, $1 \%$ vitamin mixture, $0.2 \%$ choline chloride, $0.2 \%$ DL-methionine, and $64.6 \%$ corn starch [20].

2.3. Animals and Housing Conditions. Twenty-four male albino rats (Rattus norvegicus) of East China Origin weighing 150-200 g were obtained from Faculty of Pharmacy, King Abdulaziz University, Jeddah, Saudi Arabia. All the animal experiments were carried out under protocols approved by the Institutional Animal House of the University of King Abdulaziz at Jeddah, Saudi Arabia. Animals were housed six per polycarbonate cage. Cages, bedding, and glass water bottles were replaced twice per week. The stainless steel feed containers were changed once a week.

2.4. Preparation of Methanol Extract. The methanol extract was prepared by soaking $200 \mathrm{~g}$ of each of the dry parsley seed powder and carob legumes powder in 1 liter of $90 \%$ methyl alcohol with shaking for 5 days and then kept in a refrigerator. The methanol was evaporated using a rotatory evaporator apparatus attached with a vacuum pump. Twenty grams of the semisolid methyl extract was suspended in $100 \mathrm{ml}$ distilled water with $2 \mathrm{ml}$ of tween 80 (as a suspending agent) to prepare $20 \%$ alcohol [21].

2.5. Experiment Design. The tested animals were fed with the lipid rich diet and kept under observation for 2 weeks before the start of the experiment to exclude any undercurrent infection. The rats were then divided randomly into four groups each of 6 rats as follows: the first group (G1) was the normal untreated control group fed with normal diet, the second group (G2) was fed with $2 \%$ cholesterol in the diet to induce hypercholesterolemia, the third group (G3) was fed with $2 \%$ cholesterol and cotreated with $20 \%$ parsley seeds methanol extract using stomach tube, and the fourth group (G4) was fed with $2 \%$ cholesterol and cotreated with $20 \%$ carob legumes methanol extract using stomach tube. The experiment was conducted for 8 weeks as an adequate period to induce hypercholesterolemia [22].

2.6. Physiological Evaluation. The following biological parameters were estimated: daily water consumption, daily food intake, daily body weight gain (BWG), percentage of body weight gain (BWG\%), food efficiency ratio (FER), percentage of food efficiency ratio (FER\%), and organs weight [23].

2.7. Dissection and Blood Collection. At the end of the experiment, animals were fasted 14-16 hours after their last feeding and blood was collected from the heart of dimethyl-ether preanaesthetized rats in plain tubes for biochemical analysis. Blood serum was obtained by centrifugation at $1000 \mathrm{rpm}$ for $10 \mathrm{~min}$ at room temperature and then stored at $-20^{\circ} \mathrm{C}$ until analysis was performed. Animals were sacrificed by cervical dislocation, and then the abdomen was dissected and the heart, the liver, the two kidneys, and two testes were rapidly excised and weighed. Parts of heart and liver were saved in ice-cold for antioxidant enzymes and lipid peroxidation estimation in liver and heart tissue homogenate. The other parts of the liver and the heart were saved in saline solution for histopathological investigations.

2.8. Lipid Profile. Serum total cholesterol (TC) and triglycerides (TG) were determined by colorimetric methods as described by Young [24] using Spinreact Kit (Spain) according to the instruction of the supplier. Serum high density lipoprotein (HDL) was estimated according to the colorimetric method of Naito [25] using Spinreact Kit (Spain) according to the instruction of the supplier. Serum LDL and VLDL were calculated according to the equation of Srivastava et al. [26] as follows: $\mathrm{LDL}=\mathrm{TC}-(\mathrm{HDL}+\mathrm{TG} / 5)$ and VLDL $=\mathrm{TC}-(\mathrm{LDL}+\mathrm{HDL})$.

2.9. Liver Enzymes. Serum alanine transaminase (ALT) and alkaline phosphatase (ALP) were estimated spectrophotometrically according to the method of Thefeld et al. [27] and Schlebusch et al. [28], respectively, using Human Kit (Germany) according to the instruction of the supplier. Serum aspartate aminotransferase (AST) was estimated spectrophotometrically according to the method of Thefeld et al. [27] using Swemed Diagnostics kit (India).

2.10. Lactate Dehydrogenase. The activity of lactate dehydrogenase (LDH) enzyme was estimated spectrophotometrically using Teco Diagnostics Kit (USA) as described by Martinek [29] according to the instruction of the supplier. 
TABLE 1: Effect of parsley and carob methanol extracts administration for 8 weeks on organ weight in hypercholesterolemic male rats.

\begin{tabular}{|c|c|c|c|c|c|}
\hline $\begin{array}{l}\text { Organs weight } \\
\text { g }\end{array}$ & Statistics & $\begin{array}{c}\mathrm{G} 1 \\
\text { negative control }\end{array}$ & $\begin{array}{c}\mathrm{G} 2 \\
\text { positive control }\end{array}$ & $\begin{array}{c}\mathrm{G} 3 \\
20 \% \mathrm{w} / \mathrm{w} \\
\text { parsley methanol } \\
\text { extract }\end{array}$ & $\begin{array}{c}\mathrm{G} 4 \\
20 \% \mathrm{w} / \mathrm{w} \\
\text { carob methanol } \\
\text { extract }\end{array}$ \\
\hline \multirow[t]{2}{*}{ Heart } & $\begin{array}{c}\text { Mean } \pm \text { SE } \\
\text { LSD } 0.05=0.212\end{array}$ & $0.966 \pm 0.033^{\mathrm{a}}$ & $0.833 \pm 0.061^{\mathrm{a}}$ & $0.800 \pm 0.044^{\mathrm{a}}$ & $0.933 \pm 0.095^{\mathrm{a}}$ \\
\hline & $T$-test & - & $1.451^{\mathrm{NS}}$ & $0.363^{\mathrm{NS}}$ & $-0.732^{\mathrm{NS}}$ \\
\hline \multirow[t]{2}{*}{ Liver } & $\begin{array}{c}\text { Mean } \pm \text { SE } \\
\text { LSD } 0.05=2.551\end{array}$ & $10.400 \pm 0.687^{\mathrm{a}}$ & $9.050 \pm 1.720^{\mathrm{a}}$ & $10.733 \pm 0.462^{\mathrm{a}}$ & $7.250 \pm 1.279^{\mathrm{b}}$ \\
\hline & $T$-test & - & $0.762^{\mathrm{NS}}$ & $-0.882^{\mathrm{NS}}$ & $0.916^{\mathrm{NS}}$ \\
\hline \multirow[t]{2}{*}{ Right kidney } & $\begin{array}{c}\text { Mean } \pm \text { SE } \\
\text { LSD } 0.05=0.090\end{array}$ & $0.583 \pm 0.030^{\mathrm{a}}$ & $0.633 \pm 0.0210^{\mathrm{a}}$ & $0.666 \pm 0.042^{\mathrm{a}}$ & $0.633 \pm 0.021^{\mathrm{a}}$ \\
\hline & $T$-test & - & $-2.236^{\mathrm{NS}}$ & $-0.598^{\mathrm{NS}}$ & $0.000^{\mathrm{NS}}$ \\
\hline \multirow[t]{2}{*}{ Left kidney } & $\begin{array}{c}\text { Mean } \pm \text { SE } \\
\text { LSD } 0.05=0.077\end{array}$ & $0.616 \pm 0.0166^{\mathrm{a}}$ & $0.683 \pm 0.016^{\mathrm{a}}$ & $0.633 \pm 0.033^{\mathrm{a}}$ & $0.633 \pm 0.021^{\mathrm{a}}$ \\
\hline & $T$-test & - & $-3.162^{* *}$ & $1.168^{\mathrm{NS}}$ & $1.464^{\mathrm{NS}}$ \\
\hline \multirow[t]{2}{*}{ Right testis } & $\begin{array}{c}\text { Mean } \pm \text { SE } \\
\text { LSD } 0.05=0.190\end{array}$ & $1.216 \pm 0.110^{\mathrm{a}}$ & $0.965 \pm 0.020^{\mathrm{b}}$ & $1.183 \pm 0.030^{\mathrm{a}}$ & $1.116 \pm 0.030^{\mathrm{ab}}$ \\
\hline & $T$-test & - & $2.272^{*}$ & $-5.454^{* * *}$ & $-4.373^{* * *}$ \\
\hline \multirow[t]{2}{*}{ Left testis } & $\begin{array}{c}\text { Mean } \pm \text { SE } \\
\text { LSD } 0.05=0.209\end{array}$ & $1.266 \pm 0.120^{\mathrm{a}}$ & $0.956 \pm 0.019^{\mathrm{b}}$ & $1.1500 \pm 0.050^{\mathrm{ab}}$ & $1.200 \pm 0.025^{\mathrm{a}}$ \\
\hline & $T$-test & - & $2.671^{* *}$ & $-3.15^{* *}$ & $-5.883^{* * *}$ \\
\hline
\end{tabular}

Data are represented as mean \pm SE. $T$-test values ${ }^{*}$ significant at $P<0.05,{ }^{* *}$ significant at $P<0.01$, and ${ }^{* * *}$ significant at $P<0.001$. ANOVA analysis: within each row, means with different superscript (a, b, c, or d) are significantly different at $P<0.05$, whereas means superscripts with the same letters mean that there is no significant difference at $P<0.05$. LSD: least significant difference; NS: nonsignificant.

2.11. Creatine Kinase-MB. Serum creatine kinase-MB (CK$\mathrm{MB}$ ) was estimated using the Enzyme Immunoassay method as described by Lee and Goldman [30] using Oxis kit from Oxis International Inc. (USA) according to the instruction of the supplier.

2.12. Histopathological Investigations. Parts of liver and heart were washed in sterile saline and fixed in $10 \%$ neutral formalin for histopathological studies. Tissues were then dehydrated in gradual ethanol (50-99\%), cleared in xylene, and embedded in paraffin. Sections were prepared and then stained with hematoxylin and eosin (H\&S) dye for microscopic investigation [31]. The stained sections were examined and photographed under an Olympus light microscope equipped with a digital camera.

2.13. Statistical Analysis. Mean values, standard error, and test of significance were calculated using SPSS program (SPSS version 17, Oxford University, 2009-2010, UK). The least significant value and analysis of variance were calculated using SAS package.

\section{Results}

3.1. Organ Weight. Table 1 shows the effect of administration of $20 \%$ (w/w) parsley and carob methanol extracts for 8 weeks on the weight of heart, liver, right kidney, and left kidney in hypercholesterolemic rats for two months. The mean values of the liver and the heart weights were decreased as a result of feeding rats in G2 with 2\% cholesterol in diet for 8 weeks. While the mean values of the right and the left kidney were increased as a result of feeding rats in G2 with $2 \%$ cholesterol in diet for 8 weeks, compared with the negative control. After treatment with $20 \%$ parsley seeds methanol extract in G3, the mean values of the heart, left, and right kidney weight were nonsignificantly decreased, while the mean value of the liver weight was nonsignificantly increased compared with the positive control group. In G4 which received 20\% carob legume methanol extract with diet, the mean value of the heart weight was nonsignificantly increased while the mean value of the liver weight was significantly decreased compared with the positive control group. The mean value of the kidney weight in G4 did not show significant changes.

3.2. Physiological Parameters. Table 2 shows the effect of parsley and carob methanol extracts administration for 8 weeks on physiological evaluations in hypercholesterolemic male rats. No significant difference was recoded due to hypercholesterolemia or treating the hypercholesterolemic rats with parsley or carob methanol extracts.

3.3. Lipid Profile. Table 3 shows the effect of administration of $20 \%(\mathrm{w} / \mathrm{w})$ parsley and carob methanol extracts for 8 weeks on serum lipids in hypercholesterolemic male rats. The mean 
TABLE 2: Effect of administration of $20 \%(\mathrm{w} / \mathrm{w})$ parsley and carob methanol extracts for 8 weeks on food intake (FI) body weight gain (BWG) and food efficiency ratio (FER) in hypercholesterolemic male rats.

\begin{tabular}{|c|c|c|c|c|c|}
\hline Physiological evaluation & Statistics & $\begin{array}{c}\mathrm{G} 1 \\
\text { negative control }\end{array}$ & $\begin{array}{c}\mathrm{G} 2 \\
\text { positive control }\end{array}$ & $\begin{array}{c}\mathrm{G} 3 \\
20 \% \mathrm{w} / \mathrm{w} \\
\text { parsley methanol } \\
\text { extract }\end{array}$ & $\begin{array}{c}\mathrm{G} 4 \\
20 \% \mathrm{w} / \mathrm{w} \\
\text { carob methanol } \\
\text { extract }\end{array}$ \\
\hline \multirow{2}{*}{$\begin{array}{l}\text { BWG } \\
\text { g/8 weeks }\end{array}$} & $\begin{array}{c}\text { Mean } \pm \text { SE } \\
\text { LSD } 0.05=3.781\end{array}$ & $33.16 \pm 1.641^{\mathrm{a}}$ & $29.16 \pm 0.872^{\mathrm{a}}$ & $31.33 \pm 0.843^{\mathrm{a}}$ & $29.00 \pm 1.238^{a}$ \\
\hline & $T$-test & - & $1.743^{\mathrm{NS}}$ & $-2.381^{\mathrm{NS}}$ & $0.150^{\mathrm{NS}}$ \\
\hline \multirow[t]{2}{*}{$\begin{array}{l}\text { BWG } \\
\text { g/day }\end{array}$} & $\begin{array}{c}\text { Mean } \pm \text { SE } \\
\text { LSD } 0.05=0.063\end{array}$ & $0.551 \pm 0.027^{\mathrm{a}}$ & $0.484 \pm 0.014^{\mathrm{b}}$ & $0.520 \pm 0.015^{\mathrm{NS}}$ & $0.482 \pm 0.020^{\mathrm{a}}$ \\
\hline & $T$-test & - & $1.729^{\mathrm{NS}}$ & $-2.270^{\mathrm{NS}}$ & $0.134^{\mathrm{NS}}$ \\
\hline \multirow[t]{2}{*}{$\begin{array}{l}\text { BWG } \\
\%\end{array}$} & $\begin{array}{c}\text { Mean } \pm \text { SE } \\
\text { LSD } 0.05=2.045\end{array}$ & $17.85 \pm 0.872^{\mathrm{a}}$ & $16.08 \pm 0.479^{\mathrm{a}}$ & $16.39 \pm 0.444^{\mathrm{a}}$ & $14.74 \pm 0.683^{\mathrm{a}}$ \\
\hline & $T$-test & - & $1.423^{\mathrm{NS}}$ & $-0.670^{\mathrm{NS}}$ & $2.362^{\mathrm{NS}}$ \\
\hline \multirow[t]{2}{*}{$\begin{array}{l}\text { FER } \\
\text { g/day }\end{array}$} & $\begin{array}{c}\text { Mean } \pm \text { SE } \\
\text { LSD } 0.05=0.003\end{array}$ & $0.031 \pm 0.001^{\mathrm{a}}$ & $0.028 \pm 0.000^{\mathrm{a}}$ & $0.029 \pm 0.000^{\mathrm{a}}$ & $0.027 \pm 0.001^{\mathrm{a}}$ \\
\hline & $T$-test & - & $1.612^{\mathrm{NS}}$ & $-1.282^{\mathrm{NS}}$ & $0.542^{\mathrm{NS}}$ \\
\hline \multirow[t]{2}{*}{ FER \% } & $\begin{array}{c}\text { Mean } \pm \text { SE } \\
\text { LSD } 0.05=0.274\end{array}$ & $3.166 \pm 0.149^{\mathrm{a}}$ & $2.816 \pm 0.087^{\mathrm{a}}$ & $2.933 \pm 0.084^{\mathrm{a}}$ & $2.766 \pm 0.108^{\mathrm{a}}$ \\
\hline & $T$-test & - & $1.612^{\mathrm{NS}}$ & $-1.282^{\mathrm{NS}}$ & $0.542^{\mathrm{NS}}$ \\
\hline
\end{tabular}

Data are represented as mean \pm SE. T-test values. ANOVA analysis: within each row, means with different superscript (a, b, $c$, or d) are significantly different at $P<0.05$, whereas means superscripts with the same letters mean that there is no significant difference at $P<0.05$. LSD: least significant difference; N.S: nonsignificant.

values of the serum total cholesterol, serum triglycerides, serum low density lipoproteins, and serum very low density lipoproteins significantly increase (at 0.001 ) in group 2 who received $2 \%$ cholesterol for 8 weeks. While the mean value of serum high density lipoproteins significantly decreases compared with the negative control group. The concurrent supplementation with $20 \%$ parsley seeds methanol extract in G3 and 20\% carob legume methanol extract in G4 to the hypercholesterolemic rats significantly ameliorated all lipids parameters by decreasing serum TC, TG, LDL, and VLDL and increasing serum HDL.

3.4. Liver Enzymes. Table 4 shows the effect of administration of $20 \%$ (w/w) parsley and carob methanol extracts for 8 weeks on serum liver enzymes in hypercholesterolemic rats for 8 weeks.

The mean values of ALT, AST, and ALP were significantly (at $P<0.001$ ) increased in group 2 as a result of cholesterol supplementation for 8 weeks. The concurrent supplementation with 20\% parsley seeds methanol extract in G3 and 20\% carob legume methanol extract in G4 to the hypercholesterolemic rats significantly (at $P<0.001$ ) decreased all liver enzymes during experiment period. Parsley seeds methanol extract in G3 ameliorated the liver enzymes more than carob legume methanol extract in G4.

3.5. Lactate Dehydrogenase. Table 4 also shows the effect of administration of $20 \%(\mathrm{w} / \mathrm{w})$ parsley and carob methanol extracts for 8 months on serum lactate dehydrogenase in hypercholesterolemic rats for two months. The mean value of serum lactate dehydrogenase activity was significantly (at $P<0.001)$ increased in the positive control group (G2), as a result of cholesterol administration for 8 weeks. The concurrent treatment with $20 \%$ parsley seeds methanol extract in G3 and 20\% carob legume methanol extract in G4 for 8 weeks significantly (at $P<0.001$ ) decreased lactate dehydrogenase levels in the serum of hypercholesterolemic rats under study. Parsley seeds methanol extract in G3 decreased lactate dehydrogenase more than carob legume methanol extract.

3.6. Creatine Kinase-MB. Table 4 also shows the effect of administration of $20 \%$ (w/w) of parsley and carob methanol extract for 8 weeks on serum creatine kinase-MB in hypercholesterolemic male rats. The serum creatine kinase-MB level was nonsignificantly increased as a result of induced hypercholesterolemia in G2. The concurrent treatment with $20 \%$ parsley seeds methanol extract in G3 and 20\% carob legume methanol extract in G4 for 8 weeks decreased the creatine kinase-MB and restored it to its normal levels in G1.

\subsection{Histopathological Investigations}

3.7.1. Histopathology of the Liver. Figure 1 shows histology of liver of rats under study. Figure 1(a) shows the hepatic tissue of the negative control group with normal architecture and normal hepatocytes. The portal tract shows normal bile duct, portal vein, and hepatic artery. Figure 1(b) shows the hepatic tissue of the hypercholesterolemic rats in the positive 
TABLE 3: Effect of administration of $20 \%(\mathrm{w} / \mathrm{w})$ parsley and carob methanol extracts for 8 weeks on serum lipids in hypercholesterolemic male rats.

\begin{tabular}{|c|c|c|c|c|c|}
\hline Parameters & Statistics & $\begin{array}{c}\text { G1 } \\
\text { negative control }\end{array}$ & $\begin{array}{c}\mathrm{G} 2 \\
\text { positive control }\end{array}$ & $\begin{array}{c}\mathrm{G} 3 \\
20 \% \mathrm{w} / \mathrm{w} \\
\text { parsley methanol } \\
\text { extract }\end{array}$ & $\begin{array}{c}\mathrm{G} 4 \\
20 \% \mathrm{w} / \mathrm{w} \\
\text { carob methanol } \\
\text { extract } \\
\end{array}$ \\
\hline \multirow[t]{2}{*}{$\begin{array}{l}\mathrm{STC} \\
\mathrm{mg} \%\end{array}$} & $\begin{array}{c}\text { Mean } \pm \text { SE } \\
\text { LSD } 0.05=13.878\end{array}$ & $163.50 \pm 2.81^{\mathrm{d}}$ & $273.166 \pm 5.12^{\mathrm{a}}$ & $204.33 \pm 3.13^{c}$ & $234.17 \pm 4.94^{\mathrm{b}}$ \\
\hline & $T$-test & - & $-16.06^{* * *}$ & $9.70^{* * *}$ & $4.60^{* * *}$ \\
\hline \multirow[t]{2}{*}{$\begin{array}{l}\mathrm{STG} \\
\mathrm{mg} / \mathrm{dl}\end{array}$} & $\begin{array}{c}\text { Mean } \pm \text { SE } \\
\text { LSD } 0.05=32.387\end{array}$ & $134.00 \pm 4.63^{\mathrm{b}}$ & $221.17 \pm 3.11^{\mathrm{a}}$ & $178.50 \pm 2.75^{\mathrm{a}}$ & $197.50 \pm 2.23^{\mathrm{a}}$ \\
\hline & $T$-test & - & $-13.63^{* * *}$ & $8.993^{* * *}$ & $7.10^{* * *}$ \\
\hline \multirow[t]{2}{*}{$\begin{array}{l}\text { SHDLc } \\
\mathrm{mg} / \mathrm{dl}\end{array}$} & $\begin{array}{c}\text { Mean } \pm \text { SE } \\
\text { LSD } 0.05=3.050\end{array}$ & $46.33 \pm 0.66^{\mathrm{a}}$ & $33.66 \pm 1.49^{c}$ & $40.33 \pm 0.49^{\mathrm{b}}$ & $37.00 \pm 0.57^{\mathrm{d}}$ \\
\hline & $T$-test & - & $6.35^{* * *}$ & $-3.62^{* *}$ & $-1.76^{\mathrm{NS}}$ \\
\hline \multirow[t]{2}{*}{$\begin{array}{l}\text { SLDLc } \\
\mathrm{mg} / \mathrm{dl}\end{array}$} & $\begin{array}{c}\text { Mean } \pm \text { SE } \\
\text { LSD } 0.05=13.194\end{array}$ & $90.36 \pm 2.62^{\mathrm{d}}$ & $196.33 \pm 5.21^{\mathrm{a}}$ & $127.83 \pm 2.57^{\mathrm{c}}$ & $157.17 \pm 4.80^{\mathrm{b}}$ \\
\hline & $T$-test & - & $-15.72^{* * *}$ & $10.36^{* * *}$ & $4.58^{* * *}$ \\
\hline \multirow[t]{2}{*}{$\begin{array}{l}\text { VLDLc } \\
\mathrm{mg} / \mathrm{dl}\end{array}$} & $\begin{array}{c}\text { Mean } \pm \text { SE } \\
\text { LSD } 0.05=2.222\end{array}$ & $26.80 \pm 0.92^{\mathrm{d}}$ & $44.23 \pm 0.62^{\mathrm{a}}$ & $35.70 \pm 0.55^{\mathrm{c}}$ & $39.50 \pm 0.44^{\mathrm{b}}$ \\
\hline & $T$-test & - & $-13.63^{* * *}$ & $8.99^{* * *}$ & $7.10^{* * *}$ \\
\hline
\end{tabular}

Data are represented as mean \pm SE. $T$-test values; ${ }^{* *}$ significant at $P<0.01 ;{ }^{* * *}$ significant at $P<0.001$. ANOVA analysis: within each row, means with different superscript (a, b, c, or d) are significantly different at $P<0.05$, whereas means superscripts with the same letters mean that there is no significant difference at $P<0.05$. LSD: least significant difference; NS: nonsignificant.

TABLE 4: Effect of administration of $20 \%(\mathrm{w} / \mathrm{w})$ parsley and carob methanol extracts for 8 weeks on serum liver enzymes, lactate dehydrogenase, and creatine kinase-MB in hypercholesterolemic male rats.

\begin{tabular}{|c|c|c|c|c|c|}
\hline Parameters & Statistics & $\begin{array}{c}\text { G1 } \\
\text { negative control }\end{array}$ & $\begin{array}{c}\mathrm{G} 2 \\
\text { positive control }\end{array}$ & $\begin{array}{c}\mathrm{G} 3 \\
20 \% \mathrm{w} / \mathrm{w} \\
\text { parsley methanol } \\
\text { extract } \\
\end{array}$ & $\begin{array}{c}\mathrm{G} 4 \\
20 \% \mathrm{w} / \mathrm{w} \\
\text { carob methanol } \\
\text { extract } \\
\end{array}$ \\
\hline \multirow[t]{2}{*}{$\begin{array}{l}\text { ALT } \\
\mathrm{U} / \mathrm{l}\end{array}$} & $\begin{array}{c}\text { Mean } \pm \text { SE } \\
\text { LSD } 0.05=1.471\end{array}$ & $24.00 \pm 1.06^{\mathrm{d}}$ & $65.00 \pm 0.57^{\mathrm{a}}$ & $47.66 \pm 0.55^{\mathrm{c}}$ & $56.16 \pm 0.70^{b}$ \\
\hline & $T$-test & - & $-60.01^{* * *}$ & $28.20^{* * *}$ & $53.00^{* * *}$ \\
\hline \multirow[t]{2}{*}{$\begin{array}{l}\mathrm{AST} \\
\mathrm{U} / 1\end{array}$} & $\begin{array}{c}\text { Mean } \pm \text { SE } \\
\text { LSD } 0.05=3.298\end{array}$ & $25.33 \pm 1.76^{\mathrm{d}}$ & $77.50 \pm 0.99^{\mathrm{a}}$ & $53.16 \pm 0.87^{c}$ & $66.83 \pm 0.70^{b}$ \\
\hline & $T$-test & - & $-27.64^{* * *}$ & $19.37^{* * *}$ & $12.64^{* * *}$ \\
\hline \multirow[t]{2}{*}{$\begin{array}{l}\text { ALP } \\
\mathrm{U} / 1\end{array}$} & $\begin{array}{c}\text { Mean } \pm \text { SE } \\
\text { LSD } 0.05=12.378\end{array}$ & $160.33 \pm 4.09^{\mathrm{d}}$ & $282.00 \pm 4.47^{\mathrm{a}}$ & $188.67 \pm 2.74^{\mathrm{c}}$ & $229.50 \pm 3.87^{\mathrm{b}}$ \\
\hline & $T$-test & - & $-16.83^{* * *}$ & $18.35^{* * *}$ & $7.39^{* * *}$ \\
\hline \multirow[t]{2}{*}{$\begin{array}{l}\text { Lactate dehydrogenase } \\
\mathrm{U} / \mathrm{l}\end{array}$} & $\begin{array}{c}\text { Mean } \pm \text { SE } \\
\text { LSD } 0.05=17.474\end{array}$ & $179.00 \pm 4.50^{\mathrm{d}}$ & $449.33 \pm 3.12^{\mathrm{a}}$ & $223.83 \pm 1.70^{\mathrm{C}}$ & $367.17 \pm 12.05^{\mathrm{b}}$ \\
\hline & $T$-test & - & $-54.23^{* * *}$ & $60.73^{* * *}$ & $8.03^{* * *}$ \\
\hline \multirow[t]{2}{*}{$\begin{array}{l}\text { Creatine kinase-MB } \\
\mathrm{ug} / \mathrm{ml}\end{array}$} & $\begin{array}{c}\text { Mean } \pm \text { SE } \\
\text { LSD } 0.05=1.970\end{array}$ & $20.76 \pm 0.81^{\mathrm{a}}$ & $21.01 \pm 0.72^{\mathrm{a}}$ & $20.95 \pm 0.78^{\mathrm{a}}$ & $20.93 \pm 0.77^{\mathrm{a}}$ \\
\hline & $T$-test & - & $-0.32^{\mathrm{NS}}$ & $0.06^{\mathrm{NS}}$ & $0.11^{\mathrm{NS}}$ \\
\hline
\end{tabular}

Data are represented as mean \pm SE. $T$-test values; ${ }^{* * *}$ significant at $P<0.001$. ANOVA analysis: within each row, means with different superscript (a, b, c, or d) are significantly different at $P<0.05$, whereas means superscripts with the same letters mean that there is no significant difference at $P<0.05$. LSD: least significant difference; NS: nonsignificant. 


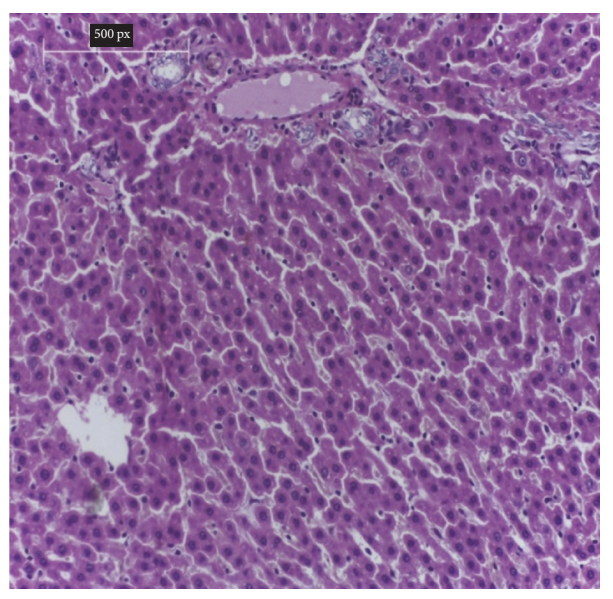

(a)

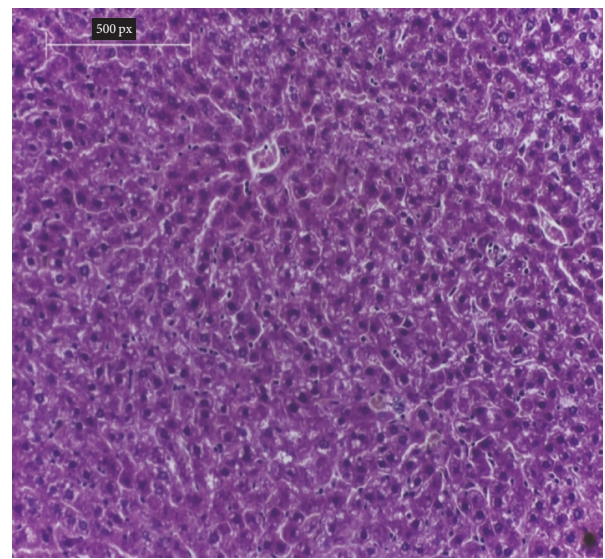

(c)

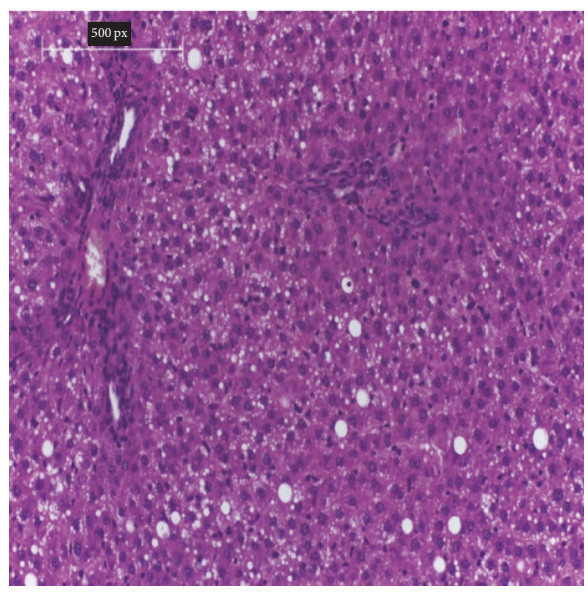

(b)

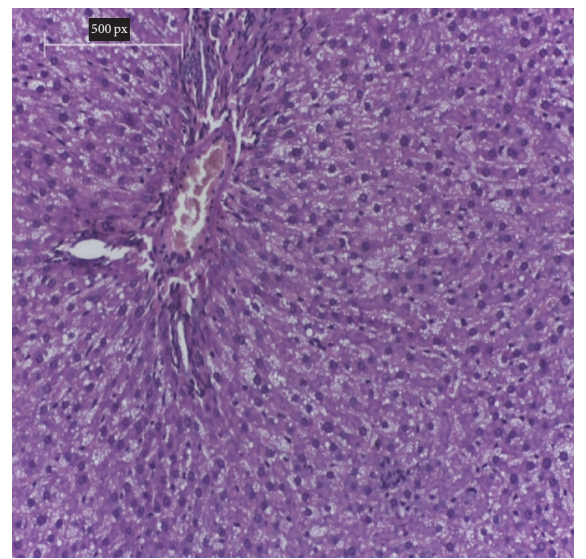

(d)

Figure 1: (a) Hepatic tissues of rat from the negative control group showing normal hepatic tissue. (b) Hepatic tissue of rat from hypercholesterolemic positive control group showing ballooning of hepatocytes, fatty changes, and inflammation. (c) Hepatic tissues photomicrography of hypercholesterolemic rat from group (3) pretreated parsley methanol extract, nearly showing normal hepatocytes. (d) Hepatic tissues of hypercholesterolemic rat from group (4) treated with carob methanol extract, showing nearly normal hepatocytes (H\&E. $\times 200)$.

control group fed with $2 \%$ cholesterol for 8 weeks with drastic alteration in architecture such as liver ballooning of hepatocytes and fatty changes, which made the hepatocytes disrupted as a result of lipid accumulation. Inflammatory cellular infiltration was also detected around the blood vessels. After treatment with parsley methanol extract in group (3) for 8 weeks, the liver showed moderate recovery from cellular damage, with nearly normal hepatocytes as shown in Figure 1(c). The liver sections of carob methanol extract treated group (G4) seemed to be restoring the normal appearance and showed minor effect of fatty changes and mild inflammation with normal hepatocytes as shown in Figure 1(d).

3.7.2. Histopathology of the Heart. Figure 2 shows histology of heart of rats under study. Figure 2(a) shows cardiac tissue of the negative control group with normal architecture of cardiac tissue and myocardial muscles. No histopathological changes were noticed. Figure 2(b) shows cardiac tissue of hypercholesterolemic rats of the positive control group fed with $2 \%$ cholesterol for 8 weeks showing changes in cardiac structure showing congestion and marked degeneration of myocardial muscles with ballooning and degeneration of cardiocytes. After treatment with parsley methanol extract in G3 for 8 weeks, the cardiac tissues showed nearly normal tissues with regenerating myocardial cells as shown in Figure 2(c). Similarly, the cardiac tissues of rats in G4 which were treated with carob methanol extract showed nearly normal tissues with residual degeneration with areas of regenerating of myocardial cells as shown in Figure 2(d).

\section{Discussion}

The present study was focused on studying the antioxidant and hypolipidemic activity of $20 \%$ (w/w) parsley seeds and carob legumes methanol extract supplementation for 8 weeks in hypercholesterolemic male rats for a probable hepatocardioprotection. The hypercholesterolemic male rats (G2) 


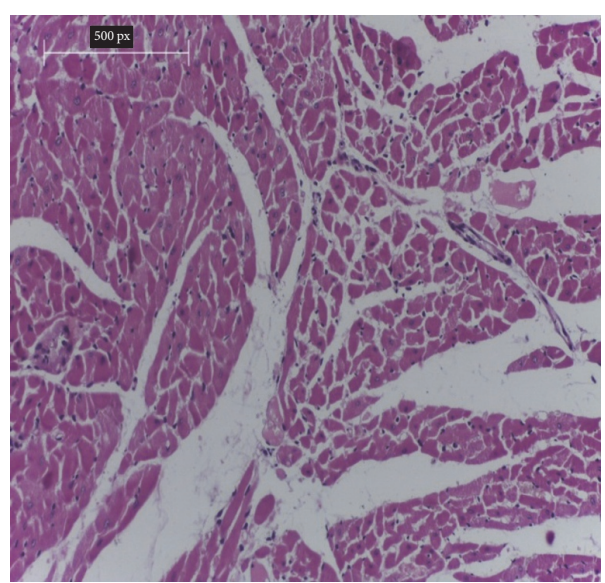

(a)

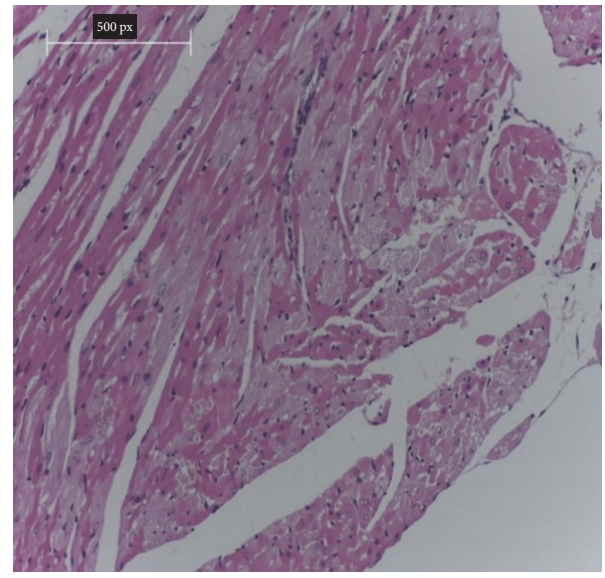

(c)

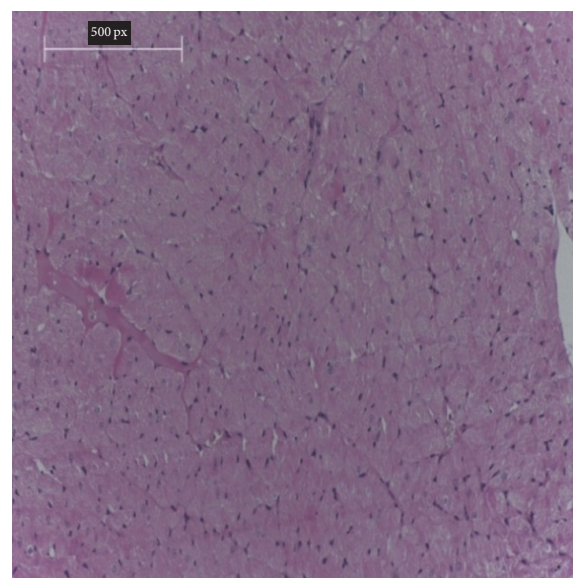

(b)

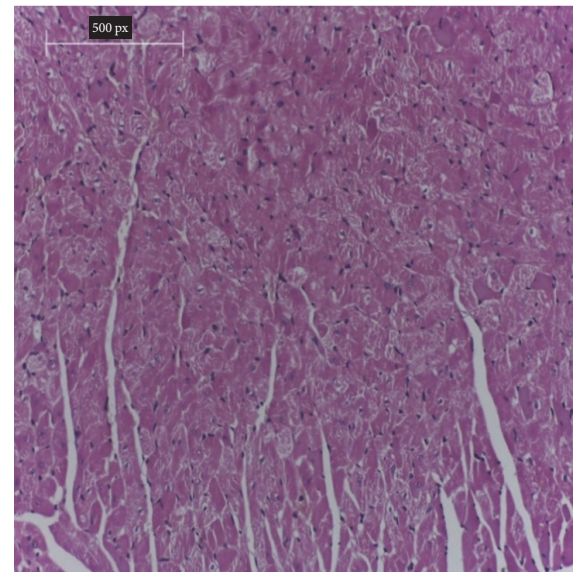

(d)

Figure 2: (a) Cardiac tissues of rats from the negative control group showing normal cardiac tissues. (b) Cardiac tissues of hypercholesterolemic rat from the positive control group showing congestion and marked degeneration of myocardial muscles with ballooning and degeneration. (c) Cardiac tissues of hypercholesterolemic rat from group (3) treated with parsley methanol extract, nearly restored their normal cardiac structure. (d) Cardiac tissues of hypercholesterolemic rat from group (4) treated with carob methanol extract, nearly restored their normal structure $(\mathrm{H} \& \mathrm{E} . \times 200)$.

treated with cholesterol ( $2 \% \mathrm{w} / \mathrm{w}$ for 8 weeks) showed a significant increase in lipid profile (total cholesterol, triglyceride, low density lipid-cholesterol, and very low density lipidcholesterol) and a significant decrease in high density lipidcholesterol. This result is consistent with previous study $[6,7$, 32]. The concurrent oral administration of $20 \%$ parsley seeds methanol extract in G3 and 20\% carob legume methanol extract in G4 to hypercholesterolemic rats for 8 weeks significantly improved the serum lipid profile parameters by decreasing the total cholesterol, TG, LDLc, and VLDLc and increasing HDLc. This result agrees with that of Ruiz-Roso et al. [33]. The hypolipidemic activity of parsley may be due to the presence of glucosinolates, betalains, plant proteins, carotenoids, and phenolic compounds [34]. It is also rich in antioxidant compounds including flavonoids, carotenoids, and other phenolic compounds $[9,35]$. On the other hand, carob is also rich in phenolic antioxidants and minerals, in addition to dietary fibers $[14,16,36]$.

Liver function parameters (serum aspartate aminotransferase, serum alanine aminotransferase, and serum alkaline phosphatase) were significantly increased in the positive control group due to induced hypercholesterolemia, compared with the negative control. This result is consistent with that of El Rabey et al. [6] and Abulnaja and El Rabey [7]. The concurrent treatment with $20 \%$ parsley seeds methanol extract in G3 and 20\% carob legume methanol extract in G4 for 8 weeks significantly improved the liver functions by decreasing the studied liver enzymes activity. Parsley seeds methanol extract showed better effect than that of carob legume. In contrast, there were no other significant differences in AST, ALP, and ALT between the beginning and the end of treatment in the subjects of insoluble dietary fiber from carob pulp preparation [33].

The markers of heart damage; lactate dehydrogenase (LDH); and creatine kinase-MB were increased under induced hyperlipidemia condition in G2 rats. Abulnaja and El Rabey [7] stated that lactate dehydrogenase is released during heart tissue damage resulting from hypercholesterolemia. The decrease of LDH as a result of the concurrent treatment with $20 \%$ parsley seeds methanol extract in G3 for 8 agrees 
with previous investigations [37]. Creatine kinase-MB (CK$\mathrm{MB}$ ) enzyme was slightly affected during the experiment but its level remained within the normal range even after treatment in G3 and G4.

The hepatic section of hypercholesterolemic rats showed disarrangement and inflammation as a result of hypercholesterolemia. Also, the heart section of hypercholesterolemic rats showed marked degeneration of myocardial muscles with ballooning of cardiomyocytes. This result is consistent with other studies showing that there is a relationship between hypercholesterolemia and pathological alteration of vital organs [7,38]. The concurrent treatment with 20\% parsley seeds methanol extract in G3 hypercholesterolemic rats and $20 \%$ carob legume methanol extract in G4 hypercholesterolemic rats for 8 weeks significantly improved the liver tissues and the heart tissue and nearly restored them to their normal state. This result is consistent with that of Kamal et al. [38].

Both parsley and carob have a protective role against many of the pathological changes due to their higher content of antioxidant substance such as flavonoids and phenolic compounds [36, 39]. Other natural products contained in olive oil and Nigella sativa also shoed hepatoprotective effect against tetrachlorocarbon hepatotoxicity [40].

It could be concluded that both parsley and carob succeeded in lowering the lipid profile levels and oxidative stress in hypercholesterolemic rats, but parsley appeared to be more efficient than carob. Moreover, the current study suggested that both parsley and carob improved the adverse conditions in hypercholesterolemic rats as shown in the heart and liver histological results. In future investigation, HPLC analysis of both extracts should be achieved in order to determine the active constituents that lowered blood lipids and protected both heart and liver.

\section{Conflicts of Interest}

The authors of this paper have no conflicts of interest.

\section{Acknowledgments}

The project was funded by the Deanship of Scientific Research (DSR), King Abdulaziz University, Jeddah, under Grant no. 319-34-أط. The authors, therefore, acknowledge with thanks DSR technical and financial support.

\section{References}

[1] M. Y. M. Van Der Wulp, H. J. Verkade, and A. K. Groen, "Regulation of cholesterol homeostasis," Molecular and Cellular Endocrinology, vol. 368, no. 1-2, pp. 1-16, 2013.

[2] S. N. Bhupathiraju and K. L. Tucker, "Coronary heart disease prevention: nutrients, foods, and dietary patterns," Clinica Chimica Acta, vol. 412, no. 17-18, pp. 1493-1514, 2011.

[3] J. G. Vaughan and P. A. Judd, Oxford Book of Health Foods, Oxford University Press Inc, New York, NY, USA, 1st edition, 2003.

[4] A. Lewis and A. Segal, "Hyperlipidemia and primary prevention of stroke: Does risk factor identification and reduction really work," Current Atherosclerosis Reports, vol. 12, no. 4, pp. 225229, 2010.

[5] P. C. Champe, R. A. Harvey, and D. R. Ferrier, Lippincott's Illustrated Reviews; Biochemistry, Lippincott Williams \& Wilkins, Baltimore and Philadelphia, Pa, USA, 2008.

[6] H. A. El Rabey, M. N. Al-Seeni, and H. M. Amer, "Efficiency of barley bran and oat bran in ameliorating blood lipid profile and the adverse histological changes in hypercholesterolemic male rats," BioMed Research International, vol. 2013, Article ID 263594, 10 pages, 2013.

[7] K. O. Abulnaja and H. A. El Rabey, "The efficiency of barley (hordeum vulgare) bran in ameliorating blood and treating fatty heart and liver of male rats," Evidence-based Complementary and Alternative Medicine, vol. 2015, Article ID 740716, 13 pages, 2015.

[8] S. Khatib and J. Vaya, "Fig, Carob, Pistachio, and Health" in Bioactive Foods in Promoting Health, R. P. Ronald Ross Watson Victor, Ed., 263, Chapter 17, p. 245, Academic Press, San Diego, Calif, USA, 2010.

[9] C. Hanrahan, J. F. Rebecca, and L. J. Fundukian, The Gale Encyclopedia of Alternative Medicine, vol. 3, Gale, Detroit, Mich, USA, 3rd edition, 2009.

[10] S. Mahmood, S. Hussain, and F. Malik, "Critique of medicinal conspicuousness of Parsley(Petroselinum crispum): a culinary herb of Mediterranean region," Pakistan Journal of Pharmaceutical Sciences, vol. 27, no. 1, pp. 193-202, 2014.

[11] A. Kurowska and I. Gałazka, "Essential oil composition of the parsley seed of cultivars marketed in Poland," Flavour and Fragrance Journal, vol. 21, no. 1, pp. 143-147, 2006.

[12] H. Zhang, F. Chen, X. I. Wang, and H.-Y. Yao, "Evaluation of antioxidant activity of parsley (Petroselinum crispum) essential oil and identification of its antioxidant constituents," Food Research International, vol. 39, no. 8, pp. 833-839, 2006.

[13] M. Snoussi, A. Dehmani, E. Noumi, G. Flamini, and A. Papetti, "Chemical composition and antibiofilm activity of Petroselinum crispum and Ocimum basilicum essential oils against Vibrio spp. strains," Microbial Pathogenesis, vol. 90, pp. 13-21, 2016.

[14] B. Haber, "Carob fiber benefits and applications," Cereal Foods World, vol. 47, no. 8, pp. 365-369, 2002.

[15] M. K. Youssef, M. M. El-Manfaloty, and H. M. Ali, "Assessment of proximate chemical composition, nutritional status, fatty acid composition and phenolic compounds of carob (Ceratonia Siliqua L.)," Food and Public Health, vol. 3, no. 6, pp. 304-308, 2013.

[16] I. Battle and J. Tous, "Carob tree (Ceratonia siliqua L.). Promoting the conservation and use of underutilized and neglected crops," in Institute of Plant Genetics and Crop Plant Research, Gatersleben, 17, International Plant Genetic Resources Institute, Rome, Italy, 1997.

[17] H. E. Hajaji, N. Lachkar, K. Alaoui et al., "Antioxidant activity, phytochemical screening, and total phenolic content of extracts from three genders of carob tree barks growing in Morocco," Arabian Journal of Chemistry, vol. 4, no. 3, pp. 321-324, 2011.

[18] H. J. F. Zunft, W. Lüder, A. Harde et al., "Carob pulp preparation rich in insoluble fibre lowers total and LDL cholesterol in hypercholesterolemic patients," European Journal of Nutrition, vol. 42, no. 5, pp. 235-242, 2003.

[19] P. A. Dakia, "Carob (Ceratonia siliqua L.) Seeds, Endosperm and Germ Composition, and Application to Healt," in Nuts and Seeds in Health and Disease Prevention, 299, p. 293, Elsevier, San Diego, Calif, USA, 2011. 
[20] J. J. Knapka and F. J. Judge, “The effects of various levels of dietary fat and apple supplementation on growth of golden hamsters (Mesocricetus auratus)," Laboratory Animal Science, vol. 24, no. 2, pp. 318-325, 1974.

[21] E. A. Adebayo, O. R. Ishola, O. S. Taiwo, O. N. Majolagbe, and B. T. Adekeye, "Evaluations of the methanol extract of Ficus exasperata stem bark, leaf and root for phytochemical analysis and antimicrobial," African Journal of Plant Science, vol. 3, no. 12, pp. 283-287, 2009.

[22] R. C. Jain, H. Khubnani, and A. Khubnani, "Action of garlic on the hyperlipidemia of experimental induced immune complex disease in rabbits," Indian Journal of Pharmacology, vol. 29, no. 4, pp. 255-257, 1997.

[23] B. Davies and T. Morris, "Physiological parameters in laboratory animals and humans," Pharmaceutical Research, vol. 10, no. 7, pp. 1093-1095, 1993.

[24] D. S. Young, Effects of Drugs on Clinical Laboratory Tests, AACC Press, Wasington, DC, USA, 4th edition, 1995.

[25] H. K. Naito, High-density lipoprotein (HDL) cholesterol. Kaplan, A. Clin Chem. The C. V. Mosby Co St. Louis, Toronto Princeton, Canada, 1984.

[26] L. M. Srivastava, N. Das, and S. Sinha, Essentials of Practical Biochemistry, CBC Publishers and Distributers, New Delhi, India, 2002.

[27] W. Thefeld, H. Hffmiester, E. W. Busch, P. U. Koller, and J. Volmer, "Reference value for determination of GOT (glutamic opal acetic transaminase, GPT (glutamic pyruvic transaminase) and alkaline phosphatase in serum with optimal standard methods," Deutsche Medizinische Wochenschrift, vol. 99, no. 8, pp. 343-351, 1974.

[28] H. Schlebusch, W. Rick, H. Lang, and M. Knedel, "Normal limits of clinically important enzymes," Deutsche Medizinische Wochenschrift, vol. 99, no. 15, pp. 765-766, 1974.

[29] R. G. Martinek, "A rapid ultraviolet spectrophotometric lactic dehydrogenase assay," Clinica Chimica Acta, vol. 40, no. 1, pp. 91-99, 1972.

[30] T. H. Lee and L. Goldman, "Serum enzyme assays in the diagnosis of acute myocardial infarction: Recommendations based on a quantitative analysis," Annals of Internal Medicine, vol. 105, no. 2, pp. 221-233, 1986.

[31] R. Drury, E. Wallington, and R. Cancerson, Carleton's Histological Technique, Oxford University Press, Oxford, UK, 4th edition, 1976.

[32] M. Cortés-Ortiz, P. Leal-Galicia, B. E. Chávez-Álvarez, M. d. Cárdenas-Aguayo, and M. A. Meraz-Ríos, "Effect of Cholesterol Enriched or Fatty-Acid Diets on Cholesterol and Lipid Levels in Young Wistar Rats," Advances in Bioscience and Biotechnology, vol. 05, no. 10, pp. 846-852, 2014.

[33] B. Ruiz-Roso, J. C. Quintela, E. de la Fuente, J. Haya, and L. Pérez-Olleros, "Insoluble carob fiber rich in polyphenols lowers total and LDL cholesterol in hypercholesterolemic sujects," Plant Foods for Human Nutrition, vol. 65, no. 1, pp. 50-56, 2010.

[34] M. M. Rashed, M. Shallan, D. A. Mohamed, K. Fouda, and L. M. Hanna, "Hypolipidemic effect of vegetable and cereal dietary mixtures from Egyptian sources," Grasas y Aceites, vol. 61, no. 3, pp. 261-270, 2010.

[35] D. J. Charles, Antioxidant Properties of Spices, Herbs and Other Sources, Springer, New York, NY, USA, 1st edition, 2013.

[36] R. W. Owen, R. Haubner, W. E. Hull et al., "Isolation and structure elucidation of the major individual polyphenols in carob fibre," Food and Chemical Toxicology, vol. 41, no. 12, pp. 1727-1738, 2003.
[37] M. A. Temiz, A. Temur, and I. Çelik, "Antioxidant Role and Hepatoprotective Effects of Carob (Ceratonia siliqua L.) Seeds against Ethanol-Induced Oxidative Stress in Rats," Journal of Food and Nutrition Research, vol. 3, no. 1, pp. 57-61, 2015.

[38] T. Kamal, E. Abd-Elhady, K. Sadek, and M. Shukry, "Effect of parsley (Petroselium Crispum) on carbon tetrachlorideinduced acute hepatotoxicity in rats," Research Journal of Pharmaceutical, Biological and Chemical Sciences, vol. 5, no. 6, pp. 1524-1534, 2014.

[39] M. M. El-Sayd Ali, A. A. Abd El-Megeid, and R. A. Mostafa, "Effect of some levels from ginseng, barley and carob on lipid profile and kidney functions of rats fed on high fructose diets," Journal of American Science, vol. 8, no. 10, pp. 152-162, 2012.

[40] M. N. Al-Seeni, H. A. El Rabey, M. A. Zamzami, and A. M. Alnefayee, "The hepatoprotective activity of olive oil and Nigella sativa oil against $\mathrm{CCl} 4$ induced hepatotoxicity in male rats," BMC Complementary and Alternative Medicine, vol. 16, no. 438, 2016. 

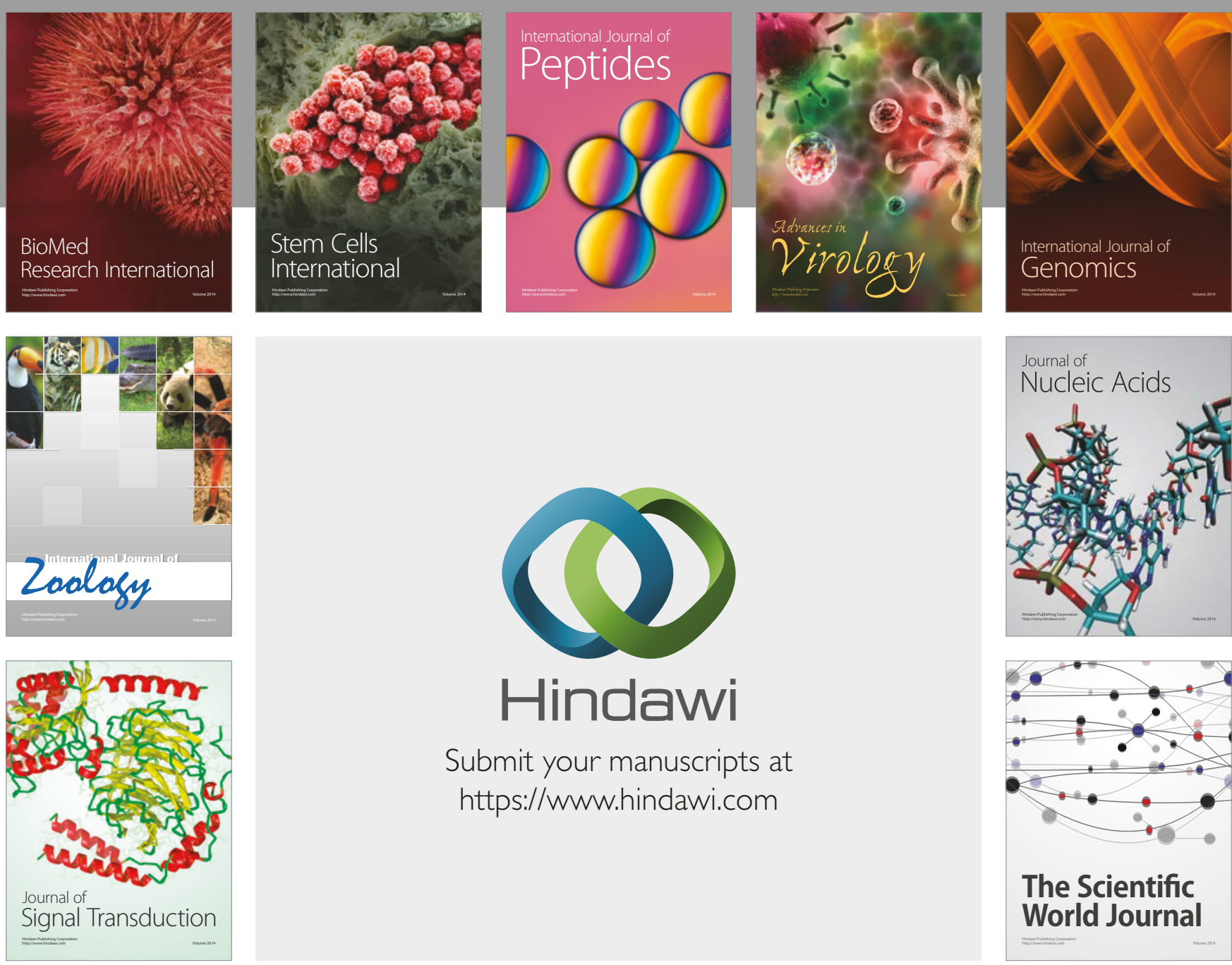

Submit your manuscripts at

https://www.hindawi.com
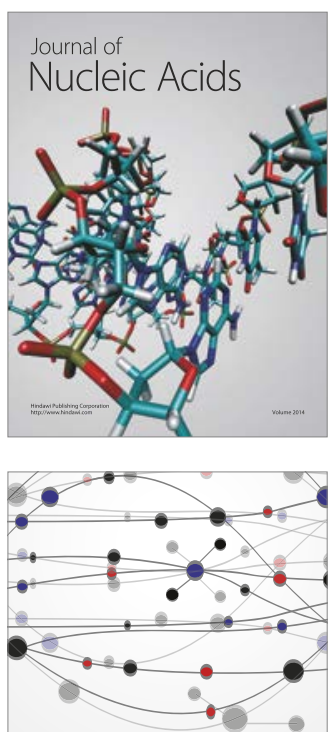

The Scientific World Journal

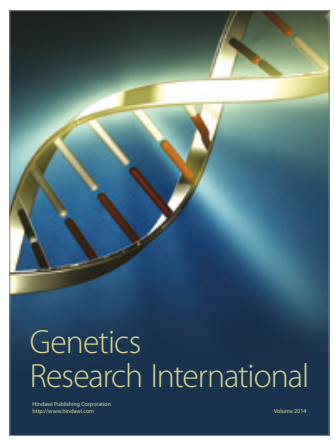

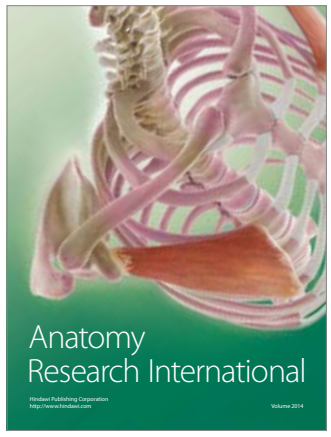

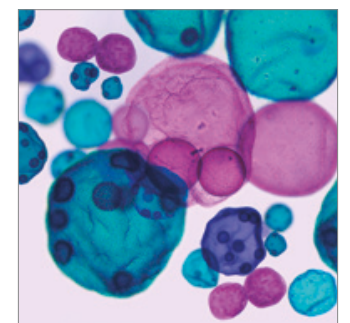

International Journal of Microbiology
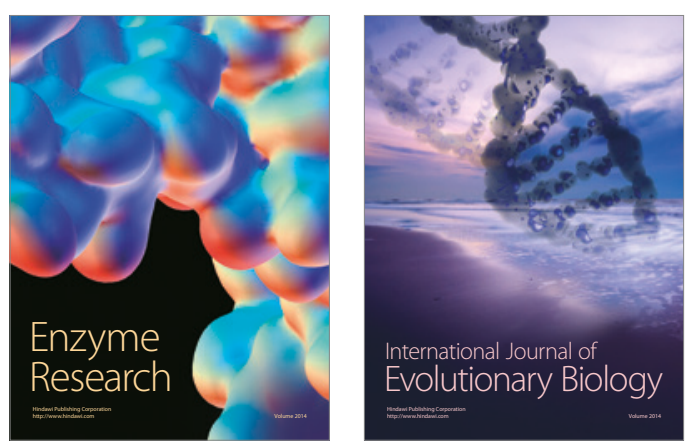
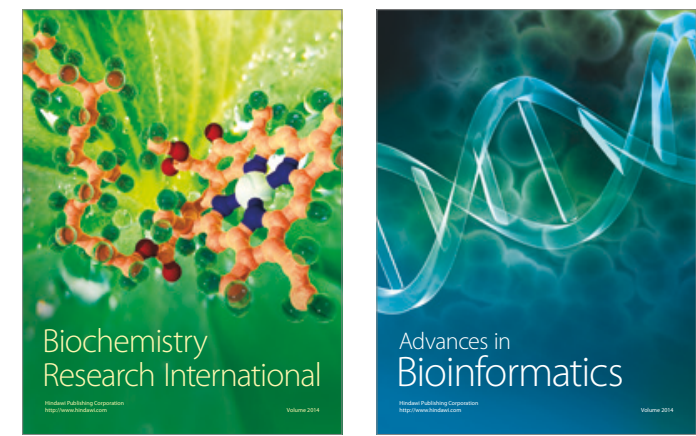

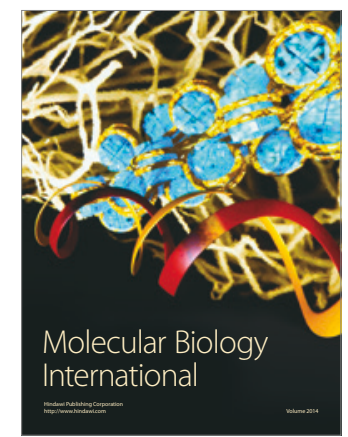

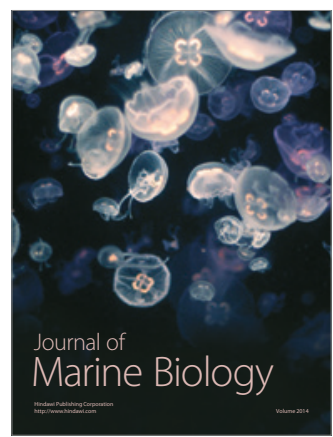

